\title{
Barriers Effect on Women Employees in it Sector
}

\author{
Magdalene Peter, S. Fabiyola Kavitha
}

\begin{abstract}
In spite of the wonderful increment in the presence of ladies in the workforce, the passage of ladies into higher managerial positions stays limited. Different examinations have affirmed this reality. This marvel of hampering women's upward progression to senior administration positions has been alluded to as the biased based impediment impact. A large portion of the nations acknowledged ladies and men are equivalent. Despite the fact that ladies couldn't leave Glass roof impact. The ladies are worried with the corporate culture and family duties. They are not ready to adjust both the family and work life. The principle goal of this examination is to assess, propose and suggest critical thinking for handling the issue of discriminatory limitation. The essential information was gathered as poll from the ladies worker. The survey was planned with six factors that are believed to be the primary factors that are purpose behind unreasonable impediment. The testing was gathered dependent on straightforward irregular examining and the device utilized is individual's $R$ and Spearman Correlation. The real finding is that the majority of the components are contrarily associated with the statistic factors. We recommend them to be increasingly obstinate and be intrepid. We might want to reason that in nation like India it is important to instruct individuals that ladies can do anything and are equivalent to men. Men should begin looking them as equivalent to them.. [1],[3],[5]
\end{abstract}

Keywords : Employee,barrier,IT sector

\section{INTRODUCTION}

Ladies agents will be versatile, empathetic, partook in a gathering and present with social affectability. At present, women have started thinking about social characteristics and ethics in light of the extension in the degree of preparing. With the methodology of the steady part in the self-perception, women are continuously taking an intrigue and progressing in the authoritative positions in their affiliations. Regardless, when in doubt, they don't find any sumptuous circumstance notwithstanding all that they comprehend an imperceptible impediment in their job way. The women in the corporate are exhausted because of the current corporate social orders and missed prospects to find successful callings. In the end, they avoid the affiliation. An unattainable position at first began during the 1980s and made as a thought by Morrison in 1987 is a jumbled impediment causing the covering of women in their employment progression. It is an unvoiced hindrance which results in less degree of women in top-level organization. The guideline limits may ascend out of society, government, internal condition, and fundamental approaches. An increasingly raised measure of confidence, resourcefulness,

Revised Manuscript Received on July 22, 2019.

Magdalene Peter, Department of MBA, Bharath Institute of Higher Education and Research, Tamilnadu, India. Email: magdalene.bsb@gmail.com

Fabiyola Kavitha, Department of MBA, Bharath Institute of Higher Education and Research, Tamilnadu, India. Email: fabiyolakavitha@gmail.com energetic leftover portion and perfect admonishment of the coaches will impact a woman to win in her transporter. [7], [ 9], [11]

As indicated by Global Gap Index Indiastands in 108 the situation out 144 nations as per most recent information of 2017(November). It says India holds $1 \mathrm{~m} 9$ position for the monetary cooperation and openings. It likewise demonstrates that India has 112 positions, 141 positions, and 15thposition in Educational Attainment, Health and Survival, and political condition individually. [2 ],[4],[6]

Men are the primary boundaries for professional success for ladies in work Place like which they can connect with themselves in spots like Reserve Bank of India. The spots like these have male-overwhelmed affiliation or relationship which can really help in imparting and sharing information. As per "Woman you're not a man-The experiences of a lady" discriminatory limitation still exist in various divisions in educational,health, media and amusement and assembling area is $67 \%, 71 \%, 60 \%$, and $63 \%$ separately. It is noticeably evident that sexual orientation separation is there in the system relationship. A male is increasingly agreeable in communicating their perspectives on people both however on account of ladies, it is hard to give suppositions and thoughts In the work environment, less help is given to ladies with respect to the help and getting to the data. Anorganization which is overwhelmed by ladies, and men arrive at an effective position is valued by both the sexual orientations. $\mathrm{Be}$ that as it may, on account of a male-dominatedorganization,successful ladies can't be taken in a positive manner by the two sexes. It is obvious that men have a preferred position over ladies in both the cases. [20], [ 22], [24]

According to European Labor Force Survey and March Current Population Survey for the United States, it expresses that ladies can overwhelm men in a specific occupation like instruction, secretaries, nursing, residential partners, key exhausted working and individual consideration. It says that a large portion of the ladies in organizations are in Nominal job or levels, not the Managerial jobs or levels. [8],[ 10] ,[12]

As indicated by Mencher Report 2009, the level of ladies worker has expanded in trough and passage level where the presence of tutoring and training and no supervisory job of less experienced staff. When you find in the directorial and top level the cooperation of ladies workers is less. Sexual orientation separation is recognizable if there should arise an occurrence of Indian IT industry is said by Ganesh Natarajan CEO, Zensar Technologies and Chairman NASSCOM. It likewise uncovers that just 35 of the female are in the top degree of $23 \%$ in IT Industry India. Fortune 2018, states that 


\section{Barriers Effect on Women Employees in it Sector}

out of 500 organizations just 24 of them are ladies CEOs.

male female proportions is $4: 1$ in enormous monster IT organizations like Google (17\% female), Pinterest $(21 \%$ female), Facebook ( $15 \%$ female), Apple ( $20 \%$ female).etc. it demonstrates the strength of male culture and detachment and ladies are misty about their profession objectives. Ladies are given badly arranged position by giving them advancement in the association contrasted with men. There are a differentsituation and diverse studies which demonstrates the unfair limitation exists among ladies workers. This examination demonstrates that the presence of an unreasonable impediment in IT organization in the general region. [13], [15] ,[ 17]

Despite the fact that there are sexual orientation enactment work laws still ladies are significantly ladies are saved money, sex contrasts and lower grade business. For an errand like directing, ladies are expected to less commendable. the unfair limitation impact is found in the administrative level for ladies. In an association the remuneration and world disposition are comparative. Issues looked by lower level position ladies are more than the official level. Ina higher level, sexual orientation basedin-balance is there all around clearly. Various elements like individual components, social variables, authoritative elements and so forth., sway the expert and family life of the ladies. [14],[16], [18]

\section{OBJECTIVES}

The objective of the study statesthe following:

1. To know the presenceofa glassceiling in the organization.

2. To know the influence of corporate hospitality and culture on the career development of women.

3 . To know the factors on the challenge aversion.

4. To analyze the productivity of women employees in an organizationand the means of eliminating inequality.

5. To recommend suitable measures for women to face a glass ceiling in their career

\section{RESEARCH METHODOLOGY}

The study is about women glass ceiling effect in different age group. It also studies the work culture and the family pressure they have. It shows the glass ceiling existence in the organization. It also shows the awareness about the inequality in opinions, performance, promotion, and compensation. The study is on the glass ceiling effect in the It organizations. The area of the study is random sampling in some places from Chennai. The study is based on random sampling. [26],[28],[30]

\section{RESULTS AND DISCUSSION}

From the analysis employed on the observations that are collected, it has been found that most of the factors are negatively correlated which implies that the increase in the responsibility of family, decreasing their performance in work life and vice versa. [31],[33],[32]
The three many years of the adventure of the metaphor"glassceiling" amongIndia evidentlyindicateditspresencebythereasonable number of concentrates on this territory. In spite of the fact that the nation is different socially, customarily and phonetically, the issues looked by the ladies for the professional success are regular in one or other regard and are assembled under the heads of - individual focused, hierarchical, social job, connection focused, human capital and inclination factors. The outcome of the discriminatory constraint generally connected to sex disparity. [25],[27],[29]Existing worldwide activities on ladies strengthening and declaration of administrative measures on ladies welfare by the numerous Indian States give a ladies strong condition for professional success. Progressively experimental examinations on various parts of biased based impediment may give a clear knowledge into ladies initiative and its obstructions. Expanding level of training and high work power cooperation of ladies make Asia a planned entryway for arriving at profession statures by either breaking the discriminatory constraint or totally obliterating it. [19],[21],[23]

\section{REFERENCES}

1. G BharthVajan R., Ramachandran S.,Psychographic dimensions of training,2016,International Journal of Pharmacy and Technology,V-8,I-4,P-23727-23729

2. Balakrishnan P., Bharthvajan R.,A study on human resource planning in hospitals in Chennai City,2014,International Journal of Applied Engineering Research,V-9,I-22,P-7503-7507

3. Priyadarsini P., Bharthvajan R.,Role of emotional intelligence training programme in reducing the stress of the nurses,2014,International Journal of Applied Engineering Research,V-9,I-22,P-7411-7421

4. Kerinab Beenu G., Bharthvajan R.,Empirical analysis on the cosmetic buying behavior of young women in South India,2014,International Journal of Applied Engineering Research,V-9,I-22,P-7361-7366

5. Balakrishnan P., Bharthvajan R.,Whistling in the wind,2014,International Journal of Applied Engineering Research,V-9,I-22,P-7586-7593

6. Krishnan B., Peter M.,Health hazards of Indian Bpo employee-an alarming issue,2014,International Journal of Applied Engineering Research,V-9,I-22,P-7336-7341

7. Kerinab Beenu G.H., Peter M.,Role of insurance in economic development,2014,International Journal of Applied Engineering Research,V-9,I-22,P-7532-7539

8. Balakrishnan P., Peter M., Priyadarsini P.,Efficiency of safety measures for wellbeing of employees in manufacturing industry,2014,International Journal of Applied Engineering Research,V-9,I-22,P-7376-7382

9. Anbarasi M., Praveen Kumar S.,Online sales promotions of herbal products and its effectiveness towards tanisha.com,2019,Indian Journal of Public Health Research and Development,V-10,I-1,P-195-200

10. Anbarasi M., Praveen Kumar S., Various online marketing and promotions strategies to improve the validation towards the organic products in the pharmaceutical sectors,2019,Indian Journal of Public Health Research and Development,V-10,I-1,P-263-269

11. Loganathan R., Praveen Kumar S.,Grievance handling a key factor for solving issues of employees in an organization,2014,International Journal of Applied Engineering Research,V-9,I-22,P-7483-7491

12. Loganathan R., Praveen Kumar S.,Study on preference of private label brands in super and Hypermarkets,2014,International Journal of Applied Engineering Research,V-9,I-22,P-7327-7335

13. Smitha M., Praveen Kumar S.,Understanding stress and its managementamong the nurses in Chennai city,2014,International Journal of Applied Engineering Research,V-9,I-22,P-7560-7565

14. Kerinab Beenu G.H., Praveen Kumar S.,A study on the investment behavior of Chennai investors in mutual fund schemes,2014,International Journal of Applied Engineering Research,V-9,I-22,P-7520-7525

15. Loganathan R., Praveen Kumar S.,Retention strategies key for organizational productivity,2014,International Journal of Applied Engineering

Research,V-9,I-22,P-7443-7447

\section{V.CONCLUSION}


16. Pavithra J., Ganesan M., Brindha G.,State wise analysis of microfinance sector in India,2016, International Journal of Pharmacy and Technology,V-8,I-4,P-23417-23432

17. Pavithra J., Ganesan M.,A comparative study on microfinance in India and abroad,2016,International Journal of Applied Business and Economic Research,V-14,I-8,P-5471-5476

18. Pavithra J., Ganesan M.,A study on awareness and impact of micro-financial schemes,2016,International Journal of Applied Business and Economic Research,V-14,I-8,P-5449-5460

19. Senthilmurugan P., Pavithra J.,Consumer preference towards organised retailing with reference to Big Bazaar,2014,International Journal of Applied Engineering Research,V-9,I-22,P-7469-7475

20. Senthilmurugan P., Pavithra J.,Implication of social media marketing in growing healthcare industry,2014,International Journal of Applied Engineering Research,V-9,I-22,P-7448-7456

21. Loganathan R., Pavithra J.,Consumer perception towards private label brand over other brands in super markets and hypermarkets,2014,International Journal of Applied Engineering Research,V-9,I-22,P-7355-7360

22. Kerinab Beenu G., Pavithra J.,Tradeâ€"off between liquidity and profitability in logistics industry,2014,International Journal of Applied Engineering Research,V-9,I-22,P-7398-7401

23. Kerinab Beenu G., Pavithra J.,A study on the prospective consumerâ€ TM $_{\mathrm{S}}$ perception towards utility cars in Chennai city,2014,International Journal of Applied Engineering Research,V-9,I-22,P-7526-7531

24. Pavithra J., Dilli Babu P., Ambuli T.V.,A study on budgetary control at Maruti Service Masters, Chennai,2014,International Journal of Applied Business and Economic Research,V-12,I-2,P-151-161

25. Pavithra J., Dilli Babu P., Ambuli T.V.,A study on customer satisfaction of retro Garments Pvt Ltd, Chennai,2014,International Journal of Applied Business and Economic Research,V-12,I-2,P-381-391

26. Kerinab Beenu G.H., Pavithra J., Senthilmurugan P.,A study on the influence of promotional activities for TATA ARIA among consumers in Chennai,2014,International Journal of Applied Engineering Research,V-9,I-22,P-7572-7578

27. Vijayaragavan S.P.,An investigative expert that's general FBG sensors,International Journal of Mechanical Engineering and Technology,V-8,I-8,PP-1500-1505,Y-2017

28. Vijayaragavan S.P.,Equalization routing protocol for Wi-Fi sensor strategy,International Journal of Mechanical Engineering and Technology,V-8,I-8,PP-1662-1666,Y-2017

29. Karthik B., Kiran Kumar T.V.U., Vijayaragavan P., Bharath Kumaran E.,Design of a digital PLL using 0.35 $\hat{\mathrm{I}}^{1 / 4 \mathrm{~m}}$ CMOS technology,Middle East Journal of Scientific Research,V-18,I-12,PP-1803-1806,Y-2013

30. Kanniga E., Selvaramarathnam K., Sundararajan M.,Kandigital bike operating system,Middle - East Journal of Scientific Research, V

31. Jasmin M., Vigneshwaran T., Beulah Hemalatha S.,Design of power aware on chip embedded memory based FSM encoding in FPGA,International Journal of Applied Engineering Research,V-10,I-2,PP-4487-4496,Y-2015

32. Jasmin M.,Optimization techniques for low power VLSI circuits,Middle East Journal of Scientific Research,V-20,I-9,PP-1082-1087,Y-2014

33. Jasmin M., Vigneswaran T.,Fuzzy controller for error control of on - Chip communication,2017 International Conference on Algorithms, Methodology, Models and Applications in Emerging Technologies, ICAMMAET 2017,V-2017-January,I-,PP-1-5,Y-2017

\section{AUTHORS PROFILE}

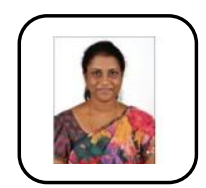

Magdalene peter Assistant Professor ,Department of MBA, Bharath Institute of Higher Education and Research, Tamilnadu, India

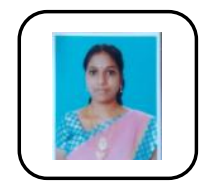

Fabiyola Kavitha Associate Professor ,Department of MBA, Bharath Institute of Higher Education and Research, Tamilnadu, India 